\title{
Self-Portrait as Critic with Body
}

That is what the highest criticism really is, the record of one's own soul. -Oscar Wilde, The Critic as Artist

We are locked into our persons as into a lasting prison. The best we can do, it seems to me, is gracefully to recognize this terrible situation and to admit that we speak of ourselves every time we have not the strength to be silent.

-Anatole France, The Literary Life

Once upon a time, in a little farming town far away, there lived the bloody shit girl. The bloody shit girl was a fourteen-year-old girl who, the day before Easter in 1978, woke up with diarrhea and throughout the course of the day flushed six pints of blood down the toilet, except that she was too ignorant to know that's what was happening because it was black, tarry, foul, partially digested blood from way up high in her intestines, and she naively thought all blood was red. At dinner time that Saturday, she mentioned to her mother, casually, that there was something particularly disgusting about this particular case of diarrhea, the stench so strong, the color so black. Her mother was slicing a loaf of French bread; the knife stopped halfway through the loaf. "That means there's blood in it," the mother said, and instructed her not to flush the toilet the next time she used it.

Less than half an hour later, the mother peered briefly into the toilet bowl before flushing it herself. "Yep, that's blood," she said to the bloody shit girl. "You must have an ulcer. Go drink some milk." It didn't occur to the mother to take the daughter to the emergency room, and it didn't occur to the bloody shit girl to think the mother should. Instead, she drank some milk as she was told; the next morning, she got up and put on her new Easter dress. In family photos taken that Sunday, the face of the bloody shit girl was hideously white above the stiff pink collar of her new dress.

The bloody shit girl was sent to the school nurse on Tuesday after Easter vacation was over and classes started again; the nurse decided there was something wrong with the bloody shit girl and so she was sent to the hospital. She had X-rays and tests and eventually 
exploratory surgery during which all her intestines were taken out of her abdomen and laid on her stomach so the doctors could poke through them, looking for tumors or wounds. When it was all over, the doctors told her, "We can't find the organic source of the bleeding, but we know that its ultimate cause is stress. You've done this to yourself, and you've got to figure out a way to stop worrying so much."

This pronouncement was something of a problem for the bloody shit girl, who hadn't realized that having a crush on a basketball player and worrying about the existence of God and wishing she had thinner thighs and was a better bassoon player, were truly matters of life and death. She hadn't managed to solve these problems when they were merely the things she sometimes cried about before she went to sleep; the fact that she might, at any minute, think a random thought that could once again cause some blood vessel somewhere to explode didn't make it any easier to keep everything under control.

The bloody shit girl lost thirty pounds as the result of the surgery. Her ribs showed through her clothing. She ate lettuce and boiled eggs. She made perfect grades. She thought more and more about the fact that she had almost bled to death - that she had almost committed suicide without even knowing it, just by worrying. She began to wonder not only about God, but about heaven and hell, and wrote about her wondering at length in her journal. She made sure she knelt in prayer at least half an hour every day. She fasted often. She read the Book of Mormon (because her church believed that was the pinnacle of spirituality) three times in one year. She was even "Seminary Scripture Chase Champion," meaning that she memorized more scriptures and could find a reference based on one or two key words faster than anyone else in her high school. She experienced spirituality as anecdotal rather than sacerdotal and got more than one scolding from Sunday school teachers and priesthood leaders who thought she asked too many questions and voiced too many odd opinions. She was earnest and sober, and nobody's idea of a fun date. She was probably too sober and serious even for God. If she'd been a little more alliterative or given to metaphor, she might have called herself the Puritan Princess of Pain, or recognized that what she was trying to be was a good old-fashioned medieval mystic. 
Both titles are anachronistic, but both fit. The bloody shit girl was a Puritan, in the way she thought of her life, in the way she wrote about it in her journal, even before her illness: after all, "While professing explicit self-denial, the Puritans engaged in obsessive selfabsorption, believing that one's life was a text to be read, read for evidences of God's dealings with the soul" (Culley 10). Perhaps the "Puritan Princess of Pain" is a somewhat redundant title-who could make sense of a "Puritan Princess of Rollicking Good Times"? Still, while the Puritans had plenty of pain, they didn't have too many princesses, and that's part of what medieval mysticism seemed to be about: being exceptional. Most medieval mystics were women, and wanted to separate themselves from the bulk of humanity in ways that would allow them to merge with the divine. The most successful of these women were

not even primarily "models" for ordinary mortals; [they were] far too dangerous for that. Like Christ himself, they could not and should not be imitated in their full extravagance and power. Rather (so their admirers say), they should be loved, venerated, and meditated upon as moments in which the other that is God breaks through into the mundane world, saturating it with meaning. (Bynum 7)

And what did their extravagance and power consist of? Mainly "a concern for affective religious response, an extreme form of penitential asceticism, an emphasis both on Christ's humanity and on the inspiration of the spirit, and a bypassing of clerical authority" (Bynum 17).

It's not just that these women weren't considered wise choices for role models; their power made them threatening in other ways as well:

By 1500, indeed, the model of the female saint, expressed in popular veneration and in official canonizations, was in many ways the mirror image of society's notion of the witch. Each was thought to be possessed, whether by God or by Satan; each seemed able to read the minds and hearts of others with uncanny shrewdness; each was suspected of flying through the air, whether in saintly levitation or bilocation, or in a witches' Sabbath. 
Moreover, each bore mysterious wounds, whether stigmata or the marks of incubi, on her body. (23)

Thus a great many of these women felt a need to defend and justify "their full extravagance and power"; some of them wrote about their lives of devotion to God, and when they did so, they tended to "use their ordinary experience (of powerlessness, of service and nurturing, of disease, etc.) as symbols into which they poured even deeper and more paradoxical meanings" (25). The reason for the asceticism, the service to others, the penitence, and even the writing, was always to demonstrate to God (and perhaps a few others, but primarily God) that they had chosen Him; and what they sought most fully was a sign that He had likewise chosen them.

Any mystic worth her salt knows that Cinderella has nothing on Mary Magdalene. Big deal: so you get a bath and some new clothes and show up at a party where a prince falls in love with you. What do you have to do to be chosen by God? What does it mean to be Jesus's darling, the first one he appears to after he rises from the dead? I don't suppose anyone knows all the answers to that question until - unless - it happens to you, but I'd hazard a guess that one thing it means is that you're really really special. The stories are basically the same, but the mystic is playing for much higher stakes. We all have use for the idea that suffering is redemptive, transformative - a pain princess knows it better than anyone. She exercises her capacity to feel, hunger and sorrow and transcendent joy, because someday, someday, God is going to come riding along with her shoe in his saddle bag, and when she puts on that rare and beautiful thing made for no one but her, the entire world will fall back and stand as contrast and backdrop to the celestial beauty of her lithe, supple, well-formed and perfect soul.

No wonder pride used to be considered the greatest sin; no wonder medieval priests were threatened by these women.

Unfortunately for the bloody shit girl, mystics got even less respect in the twentieth century than they got in the fourteenth. Or maybe fortunately. While no one arranged for her to have psychotherapy, she didn't get shut in a convent or declared a heretic, either. (Well, she didn't get shut in a convent or burned as a heretic. She did get declared a heretic. But a couple of disgruntled Sunday 
school teachers don't exactly equal an inquisition.) Instead, she edited the yearbook and spoke at her high school graduation.

The religion she grew up in, known variously as The Church of Jesus Christ of Latter-day Saints, or Mormon, or LDS, tried hard to pretend that it considered bodies cool - the point of saying otherwise was never that there was anything wrong with being located in one place, never that there was anything that wasn't GREAT about not just existing in the universe as some disembodied consciousness that could neither have an itch nor scratch it; the point was, that the bodies people had in this life were subject to death and decay as well as to works of the flesh, which were a whole separate list of nastiness, including "adultery, fornication, uncleanness, lasciviousness, idolatry, witchcraft, hatred, variance, emulations, wrath, strife, seditions, heresies, envyings, murders, drunkenness, revellings, and such like" (Galatians 5:19-21). What people needed to remember was that while the bodies dealt to us in this life came with all those problems, in the next life we'd have bodies that were just so much better. We'd all get bodies that would be like God's, who, according to Joseph Smith and all subsequent Mormon theology, has a body of flesh and bone as tangible as man's.

Mormons claim to love bodies and that's why they are supposed to take care of them and abstain from coffee, tea, tobacco, alcohol and all illicit drugs. One reason it's great to have a body is because it teaches you things that you didn't and couldn't know up in the pre-existence, back when we were all supposedly already disembodied spirit versions of ourselves - like, maybe, how to shave, and what hemorrhoids feel like.

But the biggest point in Mormon theology of acquiring a body is that it enables you to have married heterosexual sex, even in heaven, since that's what God is busy doing: how else do the spirits who end up inhabiting physical bodies in this material world get created? God gets to have multiple wives (this is the justification for the Mormons' nineteenth-century practice of polygamy) with whom he has celestial sex and celestial orgasms because of his celestial body, while his wives get to have sex with ONE partner (presumably they don't even get to sleep with God's other wives) and repeated celestial pregnancies. You can decide for yourself whether or not that's an idea of paradise that holds much attraction for you. 
Many people seem to find the story of the bloody shit girl and my explanations of Mormon theology fairly compelling, albeit somewhat gruesome and disheartening. I certainly think the tales are worth paying attention to, and manage to work my own body and my own history into most academic debates I encounter, relying for justification partly on the assertion by British anthropologist Mary Douglas that there is some use in the reductionist statement that "Just as it is true that everything symbolises the body, so it is equally true (and all the more so for that reason) that the body symbolises everything else" (123), and partly on my own sense that I have a story worth telling. I know this is seen by some readers as an act of egotism (or bodyism?), and perhaps in some ways it is, but it is also a serious attempt to come to terms, according to models and patterns I was given as I grew up, with a variety of intellectual problems.

And then there are readers interested in personal narratives who are disheartened not so much by my egotism or bodyism, but by my desire to use academic debates and literary critical theory as ways of analyzing my life. "Maybe you should just tell the story," friends have suggested, "and leave the analysis to the critics who come after you." But even my reluctance to do that has its own logic. First of all, the experience doesn't exist on its own; it's all wrapped up in my attempts to make sense of it, which became much easier once I discovered Julia Kristeva's writings about the abject. The abject is that which is composite, neither wholly this nor that; that which calls boundaries and being into question. I'm interested in ways that we move across and into margins and the discomfort and/or freedom such movement can engender. Already in this essay I've gone from third person to first person in my narration, a simple enough boundary to violate-my own voice and style-but a boundary nonetheless. The voice and intention will shift in this essay of the body, as well as in the body of the essay. At some point I'll leave the role of storyteller and move to the role of critic.

In "Autobiography as De-Facement," Paul de Man asserts that "compared to tragedy, or epic, or lyric poetry, autobiography always looks slightly disreputable and self-indulgent in a way that may be symptomatic of its incompatibility with the monumental dignity of aesthetic values" (919). De Man's comment assumes, of course, that autobiography could not be written with an interest in aesthetic val- 
ues, that aesthetic values necessarily have "monumental dignity," and that there might not be other values equally important or potentially more transgressive and challenging that autobiography could and does contain. Philippe Lejeune writes in response to critics such as de Man,

It's best to get on with the confessions: yes, I have been fooled. I believe that we can promise to tell the truth; I believe in the transparency of language, and in the existence of a complete subject who expresses himself through it; I believe that my proper name guarantees my autonomy and my singularity...I believe that when I say "I," it is I who am speaking: I believe in the Holy Ghost of the first person. And who doesn't believe in it? But of course it also happens that I believe the contrary. Whence the fascination that Roland Barthes par Roland Barthes has held for me; it seems to be the anti-Pact par excellence and proposes a dizzying game of lucidity around all the presuppositions of autobiographical discourse-so dizzying that it ends up giving the reader the illusion that it is not doing what it is nevertheless doing. "In the field of the subject, there is no referent." To a lesser degree, and more candidly, many autobiographers have outlined analogous strategies. We indeed know all this; we are not so dumb, but, once this precaution has been taken, we go on as if we did not know it. Telling the truth about the self, constituting the self as complete subject-it is a fantasy. In spite of the fact that autobiography is impossible, this in no way prevents it from existing. (131)

I also am not so dumb. I don't expect my autobiography to be seen as particularly exemplary or particularly exceptional; but I do expect both the life and the telling of it to be seen as creative acts in which I have (at least on occasion) made conscious choices regarding how I shape the material I have to work with. In "What Is an Author?" Michel Foucault calls for the creation of a space where it doesn't matter who's speaking, and argues that "the subject (and its substitutes) must be stripped of its creative role and analysed as a complex and variable function of discourse" (138); he wants to see a space where questions for consideration deal rather more with who controls the production and circulation of discourse, how a subject can enter into the discourse, and who is allowed to assume the role of subject. I wonder, however, why the subject "must be stripped of its creative role and analysed as a complex and variable function of 
discourse": whose agenda does that move further? Numerous critics who deal with issues of race and gender have pointed out that the alleged disappearance of the author coincided with a proliferation of criticism dedicated to validating and preserving writing by individuals from groups traditionally denied authority: Nancy Miller writes, in response to Foucault and others, that "the post-modern decision that the Author is Dead and the subject along with him does not... necessarily hold for women, and prematurely closes the question of agency for them" (106). I do not believe the death of the author holds for me, and I insist on keeping the question of agency as open as possible. Among the rights I claim are these: the right to narratize, the right to analyze, and the right to grieve. Furthermore, the older I get the more I value doubt, defiance, and eccentricity. Those things might be what almost killed me, but they're also what have kept me alive, and they keep life interesting, aside from just prolonging it.

In accordance with a tradition of women autobiographers whose "expectations and fears that they will be judged as women are moderated by hopes that their life stories will be useful to audiences like themselves" (Culley 11), I admit that I hope my story might mean something on a metaphysical or spiritual level to someone besides myself, and my main commitment here is to explaining some of the ways that living and then externalizing the fable of the bloody shit girl have had intellectual, metaphysical and spiritual meaning to me. If I have a commitment to anything else, it would be to exploring notions of healing and wholeness, not because I know how those things happen, but because I hope to find out. In my optimistic moments, I believe that stories can help make us well - or at the very least they can create models, vocabularies and communities to aid in our understanding of health, disease and subjectivity.

At this point, then, I want to provide you with more story. Here's one version, a poem entitled "The Paring Knife," first published in Sunstone, Vol. 19:1, March 1996:

The surgeon gave me a tight red scar and told me, "Ultimately, all that hemorrhaging has to be attributed to stress." I swear, I never meant to be so unhappy that my body offered such complete consolation. I wasn't old enough to drive but still 
I had discovered the self-indulgent vanity of a violent, accidental, self-inflicted death. And you know what?

It pissed me off. The strangled, angry cry of some lonely white girl whose parents really loved her was so shrill and harsh to me that I couldn't bear to tell myself how furious I was. How furious I am. Goddamnit someday I'll die and it doesn't seem fair that I didn't die then, lots of people die unfulfilled and young, in wars, of hunger and disease and I was so damn lucky: I got well. But I don't know: does being lucky mean I lose the right to be

but delirious with rage

not angry that my body was invaded, my gut cut neatly open, my intestines scooped out and laid on my stomach so some doctors could shove them around, look for tumors, wounds or something else of interest, lop off my appendix and sew me shut with care, then tell me when the morphine wore off that it was all my fault because I worried like an old person? "Learn to take life easy." They said that.

They really said that, to a dumb adolescent who played the bassoon, made good grades and cooked. Do you know I ate a carrot? At five thirty in the morning one Saturday I wasn't in pain but looking at my shit I knew something was wrong and I thought, Maybe fresh vegetables could help. So I peeled and ate a carrot at five thirty in the morning. And that's the image I keep close: me in my pajamas peeling a carrot at the kitchen sink, beside me stands my own death calmly, a mild annoyance since I'm too busy scraping 
the skin off a carrot to look up and know

that that shadow is dangerous and real.

I wave my paring knife at it vaguely.

I say, "You bother me. Go away."

I don't even hear it laugh at me as it

pulls my hair, shrugs, walks leisurely away.

And here's another version, in prose:

I first tried to tell my mother that something was really wrong in the early afternoon. We lived in southern Arizona and it was March and warm and gorgeous. Mom was in the backyard pulling weeds while Dad trimmed the mulberry tree. "Mom," I said, "this doesn't seem normal. What should I do?"

She stared at a branch my father was working on. "You know what to do for diarrhea," she said. "Go take some Pepto-Bismol."

It took me all day to muster sufficient courage to transgress the taboo against discussing the details of diarrhea. Helping Mom make dinner that night, I commented, "You know, Mom, this is disgusting, but there's something really wrong, I think, because this stuff, it smells worse than usual. I mean it's awful. And the other thing that's gross is the color. It's black."

She was slicing a loaf of French bread. The knife stopped halfway through the loaf. "It's what?"

"It's black."

"Holly," she said. "That means there's blood in it."

This made no sense. Blood is red. But no, she explained, new blood is red; old blood is black, like scabs. If you bleed from high in your intestines, you start digesting your own blood and it turns black. That explained the stench as well. "Don't flush the toilet the next time you use it," she said. "I want to make sure it's blood." When I called her into the bathroom she peered briefly into the bowl before flushing it herself. "Yep, that's blood," she said. "You must have an ulcer. Drink some milk." It didn't occur to her to take me to the emergency room, and it didn't occur to me to think that she should. Instead, I thought, good. I never knew what to say when people I didn't even know asked me why I looked so miserable. I couldn't very well explain to them that I sometimes sat in a dark room and hit my head against the wall because I was certain that if I didn't, I would start crying so hard that I would drown in my own 
tears, that it had to do with a tall, lanky basketball player, whom I liked, and my body, which I didn't like, as it was not lanky but ample through the hips and thighs. In my journal I wrote things like, "I'm looking forward to retirement" and the thought of all the years I'd have to endure until I was old made me extremely tired. I scrutinized my relationship with God, poking through the details of my fourteen-year-old life for some indication that He knew I existed. I was supposed to tell people this? The only answer I had used before was, "This isn't an expression; it's just my face." Now at least I could tell them it was because I was sick.

The next day was Easter-March 26 that year. Just as he did every year, Dad took pictures of all his children in their new clothes. I didn't feel good and after church I slept the rest of the day.

By Monday I was dizzy, whiny, short-tempered and scared. We didn't have school so I babysat my three younger siblings while Mom was at work. If I did anything quickly, even walk, my heart lurched and surged at an astonishing pace, the blood thrashing in my ears until I heard nothing else. But I still didn't ask to see a doctor, assuming, I guess, that if I was really sick, my mother would have dropped me off at the doctor's office on her way to work.

Tuesday school started again. I walked the three blocks to class with a couple of my friends like I always did, and they wanted to know why I walked so slowly. In band first hour I sat with my bassoon but I couldn't play it. I got to English and my teacher took one look at my pale, pale face and sent me to the nurse. I went, grateful to have someone acknowledge that something was wrong with me.

I didn't burst into tears until I got to the nurse's office. She wanted to know why I was crying but I didn't know myself. Nor could I stop crying, though I did manage to explain through my tears that I had been hemorrhaging over the weekend. Aghast, the nurse declared that I was too sick to walk anywhere; she insisted the school secretary drive me home. As soon as I was in the house, I telephoned my mother at work, who had already been called by the nurse. Mom said she'd scheduled an appointment for later in the week.

"The nurse says I need to see the doctor today," I insisted.

I could hear my mother draw in her breath. "Holly Ann, this is not a good day. I am extremely busy and besides, the earliest appoint- 
ment the doctor's office had is for Thursday. This is not a life or death situation, so you'll just have to wait until then."

And so when the doctor's receptionist called an hour later to tell me there had been a cancellation (I couldn't help wondering if the nurse had called my doctor to make sure someone took care of me), I said it didn't matter because I had no way to get there. But the receptionist must have telephoned my father because before long he showed up, got me out of the bed I'd crawled into, and dropped me off at the doctor's.

Soon I was in an examination room at Dr. Curtis's clinic. He stuck his fingers up my rectum, had a nurse draw some blood, and sent me to wait in his office. I knew, since he hadn't left me sitting in the examination room like doctors usually did, that something important was going on, though I didn't want to entertain many scenarios of what, exactly, might be wrong. I stared at photos of his family on the wall and at books behind his desk. None of the titles made sense. A few minutes later he strode in and said cheerfully, "I have some bad news. Your hemocrit count is 21 out of your normal 42."

"What does that mean?" I asked.

"It means it's a miracle that you're even still conscious. You've lost a lot of blood-I'm guessing four to six units. The human body holds 12. Quite frankly, you're lucky to be alive."

He looked at me. I knew I was supposed to say something. I searched for an appropriate response. "Oh," I said finally.

"We've got to put you in the hospital and get you some transfusions now. What's your mother's phone number?"

I listened to him tell my mother how sick I was and thought, Wow, how interesting. I didn't let myself form a sentence more specific than that; I was too bewildered by having just heard that I could have died to devote much energy to trying to make sense of the larger scope of things. I enjoyed a feeling of mild vindication, that this truly had been a matter of life or death, and that an authority figure was saying exactly that to my mother. And I was scared, of course, but not in a way that left me feeling threatened: "You're lucky to be alive" is a phrase that is both exhilarating and comforting and doesn't sound at all like "You might die soon."

Once my mother heard from an adult male that I wasn't faking, she stopped being the efficient manager of her business and became instead the efficient manager of my health. She drove me to the hos- 
pital and waited patiently through a slew of tests, the first of which were X-rays. They figured I had an ulcer, but wanted to know where it was. To make my insides glow, I had to drink twenty-four ounces of barium. It was supposed to taste like a milkshake, but it was closer to wet Comet. The X-rays took forever. The room and the table were icy, the technician prodding my abdomen and mumbling. Finally he asked, "Have you woken up at night with sharp, persistent pains in your abdomen?"

I hesitated. I had-but only once. Still, I had, so I nodded. That was sufficient evidence for an ulcer, and I was officially diagnosed, though nothing appeared on the X-rays.

Since I was to stay at the local hospital instead of going to a bigger, better equipped hospital in Tucson two hours away, I knew I wasn't sick enough to die. When I got to my room, several bouquets of flowers had already been delivered. The flowers were much more real than any pin-prick sized hole leaking blood in my intestines. I was given four units of blood in transfusion and told my body would make up the rest. I looked at the long, slender needle dripping blood into a vein in my wrist; I looked at the flowers. I didn't feel sick; I felt like a convalescent. It was romantic and unusual and my friends had already sent a message that they'd visit me the next day after school.

Although I didn't feel sick, I was treated as if I was sick: I wasn't allowed to walk to the bathroom; instead, I was expected to use a bedpan. Someone came every two hours to check my temperature and blood pressure. And my meals consisted of milk, Cream of Wheat, creamed soups, custard, Graham Crackers and bananas. No pizza, no chocolate. I could have ice cream, but it had to be vanilla, and that was hardly better than nothing.

My father - to whom I will be eternally grateful for taking me to the doctor and saving my life-brought me ice cream whenever he visited. He sat in the chair across from my bed, shaking his head, saying gloomily, "Holly, life is hard. I wish you hadn't inherited my obsessive genes. Life is hard, and it gets harder." I felt it was I who should comfort him.

Everyone but my father, though, had plenty of advice for me. I listened dutifully to all of it, especially from Dr. Curtis: "Stress kills a lot of people-not just ulcers, but heart attacks and strokes. You need to remember not to worry about things that don't matter. Take 
life easy. Be happy." The alternative, being miserable and why I might be miserable, was a topic no one brought up, and besides, it seemed so foolish now that I had confronted my own death. Anyway, what would I have told them about? A basketball player? God?

Stress kills a lot of people-not just ulcers-and I didn't have an ulcer. Nor did I have Meckel's Diverticulum or any other exotic diagnosis they tried out and rejected. I was deathly ill, but I didn't have an illness anyone could name, even after surgery-and I was sick because I worried too much about God and love and beautyeven if it was my own narcissistic concerns about whether or not God knew me, how to find love, and what beauty consisted of.

I got to go home after four days, something of a celebrity: I was the girl who worried so much she almost committed suicide without knowing it. It wasn't the greatest distinction, but it was the most interesting thing I'd done so far.

My bland diet and some prescription antacids were supposed to stop the hemorrhaging, but when it kept up, I was sent to a hospital in Tucson (we lived in rural Arizona, and Tucson, 130 miles away, was the closest large city) for tests, the first of which was a gastroscopy: a piece of fiberglass was inserted into my esophagus so my stomach and duodenum could be examined. Nothing showed up, not even an ulcer. So then I got a colonoscopy: the fiberglass tube went up my colon and still revealed nothing. I had one last set of Xrays that didn't expose a thing, and so, on April 24, I had exploratory surgery. It wasn't to cure anything, the doctors explained, but to rule out rare diseases such as Meckel's Diverticulum.

Abdominal surgery is upsetting, even if you're older than fourteen and not particularly naive. The things they do to get you ready would discompose anyone: the warm water enemas the night before, having your pubic hair shaved in order to reduce the chance of infection. Then there's the "pre-op shot," an anesthetic that feels like huge rock crystals are being forced into your muscles. Once that kicked in I began to feel drowsy, euphoric, although mildly concerned that I'd be operated on for the wrong thing. In the operating room a voice told me to take my arm out of my dressing gown so they could glue monitoring devices to my shoulder. And then my mother and an orderly were telling me to move from a stretcher back to my bed after my stint in recovery was over. 
I could hear my parents talking at the foot of my bed. I tried to open my eyes and look at them but couldn't. I hurt. I hurt everywhere: my head, my abdomen, my knees. I had an IV between the third and fourth fingers of my right hand and it was attached to a clattering, clacking machine. And I was angry. Without knowing why, I was angrier than I'd ever been in my life.

"Holly, can you hear me? We need to leave," my mother said.

"What did they find?" I asked. Somehow I already knew the answer.

"They couldn't find anything."

"Nothing? Not anything?"

"They took your appendix out and you have a cyst on your left ovary."

"Did they remove that?"

"No."

"Why not? Now I can never have children."

"Most women have cysts. They're nothing. Holly, we have to leave. I have to go to work. Your father has to go to work. But I'll be back tomorrow afternoon. ok? Do you understand? Are you going to be ok?"

I started crying. "They couldn't find anything? I feel this bad for nothing?"

"Holly, they did the best they could. Now, listen. There's one other thing. I've had surgery too, and I know how much it hurts. But remember: they won't let you go home while you're still taking pain shots. Be tough."

"Wait a minute," I said. "Why is this tube down my nose?"

"That's so you won't throw up and burst your stitches. Holly, we've got to go."

I couldn't say what I wanted to say: If you're going to leave me when I hurt this much, you can't possibly get out of here soon enough. Instead I said, "Bye." And I suppose it didn't matter that they left, since within a few minutes the anesthesia knocked me back out.

When the anesthesia finally wore off I was sure it was at least 2:00 a.m., but a nurse told me it was only 9:30 p.m. I was in a children's ward and the lights went off at 9:00 so I couldn't read or watch TV, and I was in too much pain to sleep. The severed muscles of my abdomen hurt. A spot below my waist on the right 
throbbed and burned; I realized it was where my appendix had been. My intestines had to be stuffed back through the four-inch incision in my groin after the doctors examined them, and it seemed they weren't sure where they belonged; whenever I moved, my intestines sloshed like someone had shaken a jar half filled with spaghetti. But what bothered me most was the tube down my nose. Attached to a pot on the floor, it sucked bile out of my stomach in fits and bursts. The mucus caked on it in my throat; I could hardly swallow.

Someone told me the pain shots were morphine. I'd seen enough movies in junior high health classes on "bad" drugs to know morphine was one of them, and after what my mother said to me about going home, I wasn't about to have a shot. I broke that resolution shortly after midnight. It helped but afterwards I felt guilty and weak and vowed I wouldn't have another.

It was late April in Tucson and very warm, even in the early morning. I had a fever of $101.8^{\circ}$ and was extremely uncomfortable, but I was told that fevers are normal after surgery and only treated when they pass $102^{\circ}$. The nurses offered me ice chips and 7-Up instead. By mid-afternoon the tube down my nose was driving me crazy but Ellen, the head nurse, told me that it couldn't be removed until my doctor prescribed it, that I should just be glad it was there so I didn't vomit. I didn't care.

"What about that intern Dr. Ronalds? He can prescribe it, right?" "I don't think he'll approve either."

"I don't care. If he won't take it out, I'll pull it out myself."

Half an hour later Dr. Ronalds came by.

"So this is bugging you, huh," he said.

"I can't swallow. I can't stand this. I mean I really can't stand this."

"OK, OK, we'll take it out." He grasped the tube at my nostril and pulled it out slowly. I gagged and coughed. It was two feet long and covered with bile.

"Thank you," I said. "Thank you."

I called Ellen over. "Can I have some ice?" I asked, wanting to clear away the mucus in my throat.

She pursed her lips. "You can't have any liquid. You can't have anything in your stomach. I told you you'd be better off with the tube in." 
It seemed my only option was to live with my discomfort and pain, and wait for time to pass. I lay in my bed and cried and tried not to watch the clock. My mother showed up about forty-five minutes later and was short of patience after the two hour drive, so when I couldn't speak clearly enough to tell her why I was crying, she slapped my face and told me not to be hysterical. I calmed down. I told her no one would give me anything to drink. She said, "Oh that's nonsense, Holly," and got me some ice.

A student nurse saw her feeding it to me. "Hey," she told my mother, "you can't give her that."

Mom stared hard but not at me. "Go to hell," she told the girl.

The young nurse fetched Ellen and Ellen fetched Dr. Ronalds. When Mom informed Dr. Ronalds that she was used to dealing with real doctors, he turned to me. "When was your last pain shot?" he asked.

"Midnight."

He closed his eyes and didn't breathe for a moment. "That was seventeen hours ago. No wonder you couldn't endure the tube. I told you not to be brave."

"But I want to go home," I said.

"Holly, Holly," my mother said. "I know I told you not to rely on the pain shots, but when it got that bad, you should have had a shot instead of just crying. That's how you ended up here anyway, by not being able to deal with your emotions."

"You have to realize how serious it is that you almost killed yourself this way," Dr. Ronalds said. "We didn't find the organic source of the bleeding, but the ultimate cause is stress. You can't let your emotions get out of hand."

There was nothing for me to say to that. I could only stare at Dr. Ronalds and my mother and resent them for pointing out again that this was all my fault.

In Howards End, one of the characters is thrust into a hospital against her will because, after all, "The sick had no rights; they were outside the pale; one could lie to them remorselessly" (Forster 223). I know my mother and the doctors didn't believe that I had no rights, but I certainly felt my rights were curtailed. It's true I wasn't legally an adult, and I know everyone was trying to do what was best for me, but still, I wasn't given any choice about surgery; I was simply told it would happen. Above all, I wasn't granted the right to 
ask the questions and get the answers that would help me make sense of my situation. Of course, part of the problem is that I could$n$ 't begin to pose the questions in the first place, even if someone had been willing to hear them or answer them: I had no adequate vocabulary for what was happening to me, no vocabulary for the complexities of corporeality and interiority, of illness and recovery and even of suffering, other than "I don't feel good. I'm sad. I hurt." And the lack of referentiality renders statements like that hard to decipher whenever someone makes them.

Thus it was with some satisfaction and a little vindictiveness towards my mother and the entire medical profession, as well as a great deal of personal relief, that I invented the name the bloody shit girl. It happened sixteen years after the illness, in a graduate course on autobiography in which each student was asked to name and define "the mythological self." I've spent a lot of time reflecting on the fact that when I was very young, I was forced to confront, embody, acknowledge, and think about, even if I didn't have terms for them, ideas about purity, danger, excrement, filth, and abjection, to consider and gauge the boundaries between my body and my mind, between my life and what comes out of my body, between my death and what comes out of my body - between, for that matter, my death and my life. I wasn't kidding in the poem when I said I was furious - there have been times when fury doesn't even come close - and one of the things that has continued to make me angry is the facile assertion I have encountered, in venues as disparate as graduate seminars on critical theory of the body and sessions with New Age healers, that those boundaries simply do not exist. Maybe they shouldn't exist, but that doesn't preclude the possibility that they have existed and continue to exist. A boundary doesn't have to be a clear, thick, black line in order to mark distinctions: at what point does my arm stop being my arm and become my shoulder? At what point does my shoulder stop being my shoulder and become my back? So the change is gradual; nonetheless, at some point, we are dealing with a different territory or entity. Thus I remain suspicious of all these boundaries, as well as suspicious of the possibility of doing without them completely.

The importance of boundaries in relation to the body and the ways we have of dealing with what does not respect those boundaries have been theorized by Julia Kristeva, a literary critic and psy- 
choanalytic theorist. Kristeva takes from Mary Douglas the statement that "any structure of ideas is vulnerable at its margins" (122) and applies it even more thoroughly to the body. The margins where my body is vulnerable include first of all the fuzzy line I have sketched separating my body from my mind. Another margin consists of my skin as well as certain things I keep next to it. Literary critic Elizabeth Grosz points out that "anything that comes into contact with the surface of the body and remains there long enough will be incorporated into the body images... [and] mark the body, its gait, posture, position, etc. (temporarily or more or less permanently), by marking the body image: subjects do not walk the same way or have the same posture when they are naked as when they wear clothes" (80). Still another margin is represented by substances my body produces and occasionally discards or expelsdead skin, shit, mucous, blood, etc. This is one of the margins fetishized as the abject in Kristeva's Powers of Horror.

For Kristeva, the abject, "the jettisoned object, is radically excluded and draws me toward the place where meaning collapses" (Kristeva 2). On the day between Good Friday and Easter in 1978, the day a couple of thousand years ago when Christ was dead in the grave, I woke up about 5:30 with a pain like an ice pick in my gut. Instinctively I ran to the bathroom and suddenly I was emptying my bowels of more runny stools than I ever knew my body could hold. When I finished, I stood up and stared into the toilet. Something was very wrong; I knew it. I'd never seen excrement this color before; I'd never smelled anything so foul. This had come out of $m y$ body? Standing in the bathroom, I was beset by "a massive and sudden emergence of uncanniness, which, familiar as it might have been in an opaque and forgotten life, [harried] me as radically separate, loathsome. Not me. Not that. But not nothing, either" (Kristeva 2). Or so I might have thought if I'd been more sophisticated and well-read. But at the time all I could figure was, well, maybe I hadn't been eating enough fresh vegetables. And so I went into the kitchen and peeled and ate a carrot in the vague light of sunrise before going back to bed for a few more hours.

But my bowels had not been emptied early that morning, and by afternoon I was starting to wonder how I could have diarrhea every half hour, especially since excluding the first time, nothing hurt. I didn't even feel sick. I just couldn't stop shitting. 
It was not simply because I was sick that I was a model of abjection; as Kristeva says, "It is thus not lack of cleanliness or health that causes abjection but what disturbs identity, system, order. What does not respect borders, positions, rules. The in-between, the ambiguous, the composite" (4). I didn't merely bleed; I shit blood, which is supposed to stay in veins and arteries, not show up in toilets. I shit blood that had made its way through my intestines, so that by the time I expelled it, I had literally been feeding off myself. Six units - a unit is about a pint - of it. The human body holds twelve units of blood, and I shit six. Flushed it down the toilet before I knew what, exactly, was going on. I didn't even have a wound I could identify, until the surgeon gave me a tight red scar, a kind of a tattoo, something visible that can be read. I have no marker for my internal loss other than that addition to the surface of my body.

And after that, well, I still didn't know what to think of myself. I didn't know if I was the sick me or the healthy me-or if, in fact, I had quite a new me to deal with: the once-sick-but-now-recovered me. The problem, of course, is that I didn't feel all that recovered, and my mind felt pretty much the same as it always had-it was mainly my body that felt different. No-it wasn't even that my body felt different; it's that I experienced living in it differently. Somehow I had acquired a different attitude or consciousness about what it meant to have a body. Perhaps E.M. Cioran is right when he claims that "Only in sickness do we realize how little we are in control of ourselves. Illness makes our body parts independent, while we remain their slave until the end. Illness is an organic state of consciousness, the spirit lost in the body" (Cioran 113).

Whether or not illness is an "organic state of consciousness," it does at least seem to be a consciousness different from that of health-especially if the illness in question is terminal or chronic. While it is not unusual to hear someone referred to as a cancer patient or a cancer victim, it is rare to hear someone referred to as a common cold patient or survivor - at least, I have never yet met anyone who names among his or her primary roles that of common cold patient or common cold victim or common cold survivor. And yet, basically everyone has had a severe head or chest cold. How would our experience of the common cold be different if not only western medicine but our own bodies as well were unable to over- 
come it in a matter of a week to ten days? How would the experience of sneezing and coughing and blowing your nose be different if you knew life would be like this for a couple more years, and then you'd die? How much is recovery built into most healthy persons' ideas about illness?

Thus there seems to be considerable legitimacy in the assertion that illness is as an "ontological assault, affecting our very being and not simply our activities" (Brody 29); in thinking about this assault, one must consider both the experience of being sick and how it is different from experiences of health preceding and/or following sickness:

A basic tenet underlying this phenomenology of sickness is a rejection of Cartesian dualism and an insistence upon seeing the person as a fundamental unity. Whatever the metaphysical puzzles regarding the relationship between mind and body, at the level of immediate experience, I am I, a single entity, not an admixture of mind-me and body-me. My body is not a different substance, but simply my own presence in and interaction with the world. My body moving through the world and bumping into things is simply me moving and bumping. It follows from this that, if sickness leads us to see our bodies as being something foreign, thwarting our wills by their intransigence and unmanageability, then sickness has fundamentally altered our experience of self and has introduced a sense of split and disruption where formerly unity reigned. (Brody 27)

My illness was neither chronic nor terminal; I "got well" in that, for whatever reason, I did not continue to experience the symptom of hemorrhaging. I don't know if I "caused" my recovery, but I was told that I "caused" my illness. Because my illness was, according to my doctors, brought on by my own unruly, unhappy mind, and because that unruliness of mind expressed itself so dramatically in my body, and because I was made to feel very ashamed about the whole nasty affair (my surgery wasn't even performed to correct something; it was simply "exploratory," to see if actually touching my organs could reveal something X-rays and other tests failed to show, and when it revealed nothing abnormal, nothing amiss, I had added to the burden of knowing that I'd made myself sick by worrying too much, the burden of knowing that the surgery would cost 
my parents lots of money and cause everyone a lot of trouble), because of all this, I am sympathetic when I read in Susan Sontag's Illness as Metaphor that "Psychological theories of illness are a powerful means of placing the blame on the ill. Patients who are instructed that they have, unwittingly, caused their disease are also being made to feel that they have deserved it" (57). But it is difficult to know what "psychological theories of illness" might actually be, because I am also a chronic depressive; sometimes I become unbearably sad, and that sadness makes me unable to eat or digest food or sleep and makes my skin a funny color and my tongue taste awful, and I have been sent to physicians about all this - what does it mean, that depression is now treated by doctors? Further, the doctors never told me I had caused my own disease; in fact, one of them pointed out, "Hemorrhaging is not a disease, it's just a symptom." Sontag might be able to write, about such diseases as cancer, tuberculosis and bubonic plague, that "Theories that diseases are caused by mental states and can be cured by will power are always an index of how much is not understood about the physical terrain of a disease" (55), but even that demarcation of the border between the physical and mental terrain could not be made to apply to me.

There is, within mainstream western medicine, a move away from not merely Cartesian dualism, but from "Cartesian interactionism" as well, or the idea that "physical events can causally interact with both other physical events and mental events, and that mental events can causally interact with both other mental events and physical events" (Foss 13). This position is rejected "because of the puzzling issue of psychophysical causality-how something nonphysical... can causally interact with something physical." What is embraced instead is "cybernetic interactionism," so called in order to "distinguish it from psychophysical dualism and 'interactionist' to distinguish it from a single-level, reductionist explanatory model" (13). The model of cybernetic interactionism "asserts that complex (self-organizing) systems are irreducible-their primitive unit is the loop structure of which the governing influence and the governed series of orderly processes are logically derivative" (13). An assertion such as this within western medicine acknowledges not only the "loop structure" of an embodied consciousness, but also tries to incorporate a critique of "medicine's guidance by principles that fail to acknowledge the human role in creating social 
conditions (overcrowding, crime, pollution, etc.) that themselves are agents in promoting disease" (Foss 5 ). The human patient is not seen as simply a biological organism, and is instead "at minimum a biopsychosocial system" (13).

It seems unlikely to me that a view of a patient "as simply a biological organism” is truly possible, even from a doctor; I think Sander L. Gilman is right in saying that

The infected individual is never value-neutral, that is, solely a person exhibiting specific pathological signs or symptoms. Like any complex text, the signs of illness are read within the conventions of an interpretive community that comprehends them in light of earlier, powerful readings of what are understood to be similar or parallel texts. (7)

Still, I wholeheartedly applaud efforts within the medical community to acknowledge and scrutinize the complex system that a patient is, as well as the system a patient inhabits when healthy and the system $\mathrm{s} /$ he enters when ill. One consequence of this effort is that it increases the areas of my life that seem legitimately affected by my own physical distress: treatment of me starts with the recognition that illness impacts my life in multiple ways, and I have multiple ways of thinking about such impacts. This thinking is going to involve such humble metaphors as my life up to that point has afforded. In her condemnation of the use of illness as a metaphorbecause it is insulting to sick people (i.e., Naziism as a cancer)Sontag fails to take adequately into account that not only has illness been used to represent other states, but that other states have been used to represent illness, and that some of them have been seen not only as metaphorical, but as transcendental.

Caroline Walker Bynum's Holy Feast and Holy Fast is subtitled The Religious Significance of Food to Medieval Women and contains attention not just to eating, but to a range of corporeal experiences, including illness. Her study points out that among other things, sickness has been seen as a sign of grace, a chance to develop the soul and conquer the body. Bynum cites one woman who "suggested that if people knew how useful diseases were for self-discipline, they would purchase them in the marketplace" (200). Illness offered not just self-discipline but "suffering; and suffering was considered an effective activity, which redeemed both individual and cosmos" (207). 
Even a modern-day hagiographer (albeit not one concerned with Latter-day Saints, just good old-fashioned canonized ones) such as E.M. Cioran writes

Without illness there is no absolute knowledge. Illness is a primary cause of history; sin, only a secondary one.

Consciousness is a symptom of estrangement from life caused by illness. Everything that is not nature was revealed to the first sick man when he looked up at the sky for the first time. (95)

I certainly strove to make sense of my illness - which aside from the extreme, excruciating, prolonged, painful trauma of abdominal surgery, really didn't hurt very much, which seemed weird to me; I remember thinking, "if my body is busy killing itself, shouldn't I be able to feel it?" - in terms of increased consciousness and suffering and how they could redeem or improve me. For a while I claimed to be grateful for my unsolved illness because "it taught me something" - my own version of Cioran's absolute knowledge, I suppose. In my journal, I wrote that the experience taught me that I was utterly dependent on God for comfort. Twenty years later, a few more illnesses (though none so dramatic) and a few crises of faith later, what I've learned is not so fixed or absolute. Certainly the prebloody shit girl was ignorant, ignorant; but did I as the bloody shit girl learn anything true? A lesson I internalized quite thoroughly and am still trying to unlearn is that bodies are revolting, treacherous things, and there are far better reasons to hate them than what they might look like: bodies will get sick without permission, they will ignore commands to sit up or roll over, they will hurt until the pain makes you into someone you never knew existed, and ultimately you're better off without one-death might not be such a huge punishment and resurrection might not be such a big reward after all.

That distrust of my body has made me at times observe obsessively my bodily habits and functions. I have read The Merck Manual, a diagnostic handbook for doctors, sometimes simply for pleasure, and assessed my pulses and pains and palpitations as possible symptoms of diseases both rare and mundane. This makes me a hypochondriac. I asked one of my closest friends, a doctor who trained at one of the most prestigious clinics in the country, what 
kind of patient he and his colleagues across the continent would consider me, if I showed up in their offices, clearly a lay-person but clearly conversant in medical jargon about symptoms and conditions. "Oh, we'd probably call you a GOMER," he admitted reluctantly, GOMER being an acronym for Get Out of My Emergency Room.

Since after my illness I'd learned to distrust my body-it wasn't a safe place to live-I began living in my mind, more and more. I ate as little as possible-I was so thin that my ribs showed through my clothes - and I spent lots of time reading big books of scripture. I'd been concerned with God even before I got sick, but having come so close to dying, I thought I might already have some idea what it would feel like. I wanted to be ready to meet God; I wanted to be as intimate with Him and His mystery as I was with death and its mystery. And so I read scripture and fasted and prayed and wrote at length in my journal. I strove to synthesize everything I read into some coherent whole.

After that, I still had the task of telling everyone first of all, what I'd figured out, and secondly, how I'd arrived at those conclusions. When I was about twelve, Spencer W. Kimball, the prophet of the Church, published a talk advising the youth of the Church to

Get a notebook... a journal that will last through all time, and maybe the angels will quote from it for eternity. Begin today and write in it your goings and comings, your deepest thoughts, your achievements and your failures, your associations and your triumphs, your impressions and your testimonies. (5)

I was already a saint - I was born into a family of Saints - I grew up singing a hymn called "Come, Come Ye Saints" and when we had lessons in Sunday school about the Mormon migration to Utah, we referred to it as "The Saints crossing the plains." At age eight, I was baptized and confirmed a member of the Church: because my body was immersed in water, my soul was washed clean, and I became an official member of the body of Saints. But President Kimball dangled in front of me the possibility of being a prophet: someone whose writings are canonized.

Mormonism, like Puritanism, depends on testimony, on making public professions of faith, and on the narrating of experiences that cultivate faith. Telling personal stories to a public audience is a 
habit I can't shake, even now that I've left the Church, because I think that personal narratives matter. oK, maybe I'm stuck-up, like a billion other essayists and writers: Joan Didion claims that "In many ways writing is the act of saying $I$, of imposing oneself upon other people, of saying, listen to me, see it my way, change your mind. It's an aggressive, even a hostile act" (172) and E.B. White admits, "I have always been aware that I am by nature self-absorbed and egoistical; to write of myself to the extent I have done indicates too great attention to my own life, not enough to the lives of others" (viii) and the professor in a graduate seminar once wrote to inform me that "I think you should reconcile yourself to the fact that nobody else on the face of this planet (or in heaven or in hell or on the North Pole, for that matter) is likely to be as obsessed with or even as interested in your bodymindsoul as you are." Well, I never expected anyone to be as interested in my life as I am, but that doesn't mean everyone is uninterested. Furthermore, the fact still remains that I grew up in an odd community where writing one's life story is not just an oK thing to do but a commandment, and that occasionally outsiders have noticed how this commandment influences not only the way stories are told but how they are heard.

For instance, the December 1995 issue of Sunstone, an intellectual magazine of Mormon experience, scholarship, issues and art, contains an article entitled "Teaching Confessions to Saints: A NonLDS Professor and her LDS Students," written by Linda Rugg, who took a sabbatical from Ohio State University to accept a position as a visiting professor at Brigham Young University, which is owned and run by the Mormon Church. Rugg taught a course on "the admittedly esoteric topic of Scandinavian autobiography" (13); the reading assignments included essays by Foucault, de Man and Lejeune, arguing various positions about the role of the author and the nature of autobiography. Rugg writes,

I had not reckoned the impact of such ideas in a community where testimony is of central importance.... What fascinated and excited me as a teacher was the stake my students had in these ideas. It was not simply an academic question, as it had been in classes I had taught at osu, of understanding difficult theories. The BYU students were quick to understand precisely because they had to take a position regarding testimony, selfhood, and authorship. What if, one of my students asked, we say that Joseph Smith is an author 
function? Because Joseph Smith is understood to be a prophet, an individual chosen by God to reveal truth, is it not important that we understand his texts as written by his hand? Would it make a difference if we discovered that some of the texts ascribed to Joseph Smith were produced by another person, not a prophet? Are the texts received as prophetic because a prophet writes or speaks them, or is an individual prophetic on the basis of his or her texts? What about the issue of truth value? Suddenly we were working with a theory that mattered, not an abstraction or a game. (14)

Perhaps there are other questions floating around in contemporary literary theory that would "matter" equally to other intellectual subsets of a religious community. When I read Judith Butler's statement in Bodies That Matter that she wants "to ask how and why 'materiality' has become a sign of irreducibility" (28) and noting that "it seems that when the constructivist is construed as a linguistic idealist, the constructivist refutes the reality of bodies, the relevance of science, the alleged facts of birth, aging, illness, and death" (10, emphasis added) I can't get over how much she has in common with a Christian Scientist or a New Age health guru: why are those facts "alleged"? Who among us has been able to refute or overcome them, and how do those who witness the refutation or defeat of death or aging or illness respond to it-besides, for instance, by bearing testimony? How do those who hear the testimony respond to it? More specifically, did Jesus really heal the sick and rise from the dead, or not? And if not, is faith healing and eternal life still available to the rest of us in some way? What if you're not Christian? What about reincarnation?

Of course, Butler poses other questions as well:

How, then, can one think through the matter of bodies as a kind of materialization governed by regulatory norms in order to ascertain the workings of a heterosexual hegemony in the formation of what qualifies as a viable body? How does the materialization of the norm in bodily formation produce a domain of abjected bodies, a field of deformation, which, in failing to qualify as the fully human, fortifies those regulatory norms? What challenge does that excluded and abjected realm produce to a symbolic hegemony that might force a radical rearticulation of what qualifies as bodies that matter, ways of living that count as "life," lives worth protecting, lives worth saving, lives worth grieving? (16) 
Many critics, like Mormons, claim to believe that bodies are cool. It has been suggested to me that the "point that critics have bodies is by now a commonplace. Actually, it has probably been a commonplace ever since that ur-critic Socrates was fondled by Alcibiades in The Symposium, and then died from ingesting hemlock into a lessthan-ideal body. But extensive analysis or meditation on what it means for critics to have bodies and how those bodies-not just bladders, but bodies-affect their work is not commonplace-it's not even commonplace among doctors or patients.

In "Me and My Shadow," for instance, it does not seem to be Jane Tompkins' intention to foreground her body. Her references to needing to pee while writing the essay are reminiscent of Virginia Woolf's mention that she's been doodling angrily as she does research in the British Library for A Room of One's Own-doodling done with a hand, a hand attached to a body. Tompkins doesn't remind us that she has a body as much as she announces that she has a life and a set of interests separate from academia, and that she, like Woolf before her, is angry at the way women and the reality of their lives are excluded from academic discourse. Tompkins excludes most of her body from the essay; we don't even find out, for instance, if being angry makes the need to pee more or less urgent.

Thus, the posing of Butler's main question of "which bodies matter, and how, and why" is a good and useful enterprise for both critics and everyone else, and one that still is not often pursued, but should be. It's a question I care about - I want to understand how and why bodies that are not mine matter, and I want to understand how it is that some bodies are made not to matter-and yet, if I can begin to formulate any answer to it at all, I must first sort out my testimony about $m y$ life and my body - and not because I'm egocentric, but because this is the body I live in. I remember, before I started hemorrhaging, obsessing over my body shape, which I didn't like, and a basketball player, whom I did. Would I have avoided getting sick and almost dying if gender roles were different, if ideals for female attractiveness were less narrowly defined? I also wonder if I would have been treated differently by the doctors if I had been a boy and somehow suffered the same problem. I suspect that the fact that I was told to go home and heal my mind (which is not matter) and thus my body (which is matter and which seemed to matter 
more than my mind) on my own has roots in a phenomenon noted by Bynum:

But for the late Middle Ages there is clear evidence that behavior and occurrences that both we and medieval people see as "illnesses" are less likely to be described as something "to be cured" when they happen to women than when they happen to men. Women's illness was "to be endured," not "cured." Patient suffering of disease or injury was a major way of gaining sanctity for females but not for males. (Holy Feast 199)

And I might also ask how I would have been treated differently had I and my parents not been white and middleclass. Sander L. Gilman points out that

in contemporary America there is an assumption among physicians that the diseased and the beautiful cannot be encapsulated in one and the same category. Young physicians often see beautiful patients as exemplary or "good" patients, patients who will follow doctor's orders and therefore will regain health. The aged or poor patient, on the other hand, is seen, even by the trained physician, as one who is a "bad" patient, a patient who will probably "make trouble" and whose health will not improve. Indeed "lower-class" patients were often diagnosed as being more gravely ill and were given poorer prognoses than those of other social classes when, in fact, they differed from those patients only in terms of the visible (or stated) criteria of class. (4)

But the fact remains, regardless of any alternative scenarios I might imagine, regardless of whether or not some alternative discourse might have allowed me to perform a different way of embodying the white, female, middleclass, free of major disfigurements, born in 1963 and currently 5'6" body I am/have/inhabit, that I didn't have anything that could be diagnosed, that I got medical care in the form of necessary transfusions adequate at least to save my life, and that I think of my mind as affected and impinged upon by my body, that despite the doctors telling me that my mind threatened my body, nonetheless I imagined my mind as me and I imagined my body as that which interfered with the me-ness of me. I am not the only one who has felt this way; I am not the only one who makes and has made a distinction between my body and me. As Caroline 
Bynum points out, "if my body is not simply a synonym for me, I must, by using the term, raise questions about some particular aspects of the self" ("Medievalist's Perspective" 2-3).

I don't pretend to have answers to the questions I'm raising about any particular aspect of the self, because I'm still conflicted about whether or not I want to have, all the time, some unified sense of mind/soul/body. Most of the time, I think, well, of course I want to experience being me in the most holistic, complete way possible. But right now I'm fairly healthy and things might change if I got sick again. I'm aware, also, that there are times when a dissociation from one's body might seem not only the logical response to a situation, but perhaps the healthiest one as well-during or following sexual assault, for instance.

And so I have few answers, or else too many answers, and no way to decide which answers are right, and still more questions I would like to pose. Some of them are ugly, as abject, almost, as their subject matter: what does it mean to grieve over shit? Perhaps it is either a renunciation or an embracing of shame. But I think it is also a fundamental recognition of something abjection tells us: that the power to blur boundaries is a terrific power, though both the power and the blurring can be extremely costly.

Another question: would each moment have mattered more, would the grieving have been more a part of the moment and not of the memory, if every time I flushed the toilet I had known that my heart had less blood, less of me to supply me with oxygen? Well, of course; of course it would have changed some things if I had known what was making all that excrement so black and foul and tarry; I would have paid more attention and been more afraid if I had known I was in some literal way, flushing my life down the toilet. But it's not as if I could have done anything to reclaim my blood and purify it, instead of having several pints of someone else's (possibly contaminated) blood pumped into my veins. On some level I did know I was audience to a graphic spectacle of loss; I was confronting a previously useful and wholesome part of myself that had become so defiled, so loathsome, that it could never be integrated into the whole again. I just didn't know how deep that level was, or how vast the spectacle, and while I'd had plenty of training in how to be witness to my own behaviors, I didn't know how to witness my own confusion, and I didn't know how to ask anyone else to wit- 
ness my confusion as well. And I needed another witness, for all kinds of reasons. In the United States, a last will and testament is valid only if it is either written entirely by hand, the handwriting throughout recognizable as that of the person who signs it; or else if it is signed by two witnesses. Some spectacles of power are too awful to watch alone.

I also have questions about my mother, about the ways in which I, who lived inside her, who was of her but not her, could and should matter to her. My ancestors were Mormon pioneers who endured intense hardship - religious persecution and attacks by Indians on the warpath - they didn't even have emergency rooms; my mother grew up with a frontier mentality. Still, if you knew your child was shitting blood, wouldn't you take him or her to the hospital, provided one was available, right away? My mother certainly adheres to her own creed of stoicism: I found out when I was about thirty that she was born with an extra vertebra, and it has caused her discomfort all her life. Not until she was unable to lift anything did she tell her children or her husband about this condition. She's an accomplished musician, a successful business woman, and an effective politician. I know she has never ever intended to hurt me, and she has nurtured and supported me in a number of important ways. Sympathy, however, is not her strong suit. Her skepticism about the seriousness of my illness seemed to me to be indifference to my suffering, and the stoicism she expected from me seemed like cruelty. I know it's important to forgive both her and myself for what happened; in some ways I succeed and in some ways I don't. What is the relationship of forgiveness to abjection? Is forgiveness a gesture that affirms and accepts what is fundamentally incomplete and lacking, or could it be a gesture that somehow provides what makes something whole, even if imperfectly whole?

And what is the role of language? If I had been better able to express my fear, my discomfort, would she have taken me to a doctor that Saturday night? Would the source of the bleeding have been found if I'd gotten to the hospital sooner, if I'd better understood what the X-ray technician was asking me when he said, "Have you woken up in the night with sharp pains in your abdomen?" Would I then have a diagnosis instead of a mystery?

Cioran writes that, "If you believe in God, you are mad without having gone mad. It is similar to being sick without suffering from 
any specific illness" (116). This was certainly the case with me. As the doctors pointed out to me, I had nothing but a symptom, and Kristeva claims that "In the symptom, the abject permeates me, I become abject" (11). How nice it would have been to have had more than a symptom, to have had a name, an explanation for what happened, besides "the thing that I did to myself." If "abjection is therefore a kind of narcissistic crisis [that] is witness to the ephemeral aspect of the state called 'narcissism' with reproachful jealousy" (14), is it any wonder - especially considering the directive I was given as an adolescent to puzzle out my life in a journal - that I try to solve my narcissistic crisis by writing about that thing I did to myself, since "writing then implies an ability to imagine the abject, that is, to see oneself in its place and to thrust it aside only by means of the displacement of verbal play" (16)?

Kristeva, trained in Freudian psychoanalysis, breaks down the father-mother-child triad and relegates the verbal to the realm of the father; the physical, the nurturing and life-sustaining belong to the realm of the mother. The child ceases to be one with the mother and loses the comfort and materiality of the breast; the breast is replaced with the cold but necessary abstraction of language. When I groped to express my increasing sense that something, something was horribly wrong, my mother, the absent breast, told me in the language of the father to drink some milk. Too late! The wholeness is already ruptured. That which is not me cannot take care of me, cannot make me whole. Neither can that which is me care for me or keep me whole.

And what is the whole I would want to keep? A pre-lapsarian trust in my body, or at least trust that I knew what was going on with my body - that it sent me honest signals? Faith in my ability to communicate to others the nature of my suffering and to request the care I required in order to live? Faith in their willingness to hear and respond to such communications?

Certainly those are all elements of what I mourn, what I lost. What I gained is knowledge, and I'm not sure what that knowledge is worth - and the price I might have paid for it is part of what has angered me.

The Church taught me: my writing is canonizable-it can be included in the works officially recognized as scripture, it can become a basis for judgment, a standard, a criterion. 
My illness taught me: my body is cannibalizable.

I've borrowed and plagiarized from my own work enough, revised poems for ten years before finally abandoning them as fodder for new poems, to know that my writing is cannibalizable too.

Is my body canonizable? Can it become a basis for judgment, a standard, a criterion?

If not, why not? If so, how?

There's something going on here in this issue of canonize and cannibalize besides just a pun, something involving more puns about remembering and dismemberment, about passion as suffering and passion as love, about wholeness and holiness. What is the relation of an abject body to any canonizable work it produces? Is writing a means to canonization for the body, for the life that leads to certain types of writing? Does experiencing the abject and living in the margin mean you have a better vantage point from which to assess the whole and find clarity? If you lose something and then renounce the hole it used to occupy, do you then become whole? If wholeness through writing isn't possible, are an exploration of ignorance, a search for mystery, a moment at which the self that watches encounters the self that is watched, still all valid impetuses for writing?

I don't know. I can tell you that I hope so. I can tell you what I used to believe most strongly: it seemed to me, at age fourteen, that I was very lucky in that no one was going to subject me to intentional cruelty, and that I owed the universe gratitude for allowing me to escape greater suffering, but still, I did not have the right to demand from anyone care or attention, that my life was not as important as other peoples' convenience, that I was as much an abjected expelled substance to my mother as my own bloody shit was to me, that the woman who bore me and gave me my life, did not really value my life, and so I was foolish to value it myself.

And yet I do value my life. It's not so much that it's noble or paltry as that it's mine and while there are many things I should value in addition to my life, there is nothing I should value instead of it. And despite my mother's unwillingness to take to me to the hospital when she realized I was shitting blood, I still know she loves me; and despite my distress at being subjected to unnecessary exploratory surgery I still know that western medicine isn't entirely worthless. And I don't even particularly distrust my body any 
more: I've discovered yoga in the past few years and done enough of it to know that bodies can be, if you get something just right-I don't know if it's a mental attitude, or a physical state or a level of spiritual enlightenment - the coolest toys in the universe.

If I were a decent critic, perhaps I'd heed my Sunday school teachers' and priesthood leaders' exhortations to stop asking so many questions and stop voicing so many odd opinions; perhaps I'd invent more answers to the questions I've posed, or else select one answer and leave it at that. But I am not a decent critic. I gave up the right to that title as soon as I wrote the sentence, "What does it mean to grieve over shit?" and admitted that I shit blood and mourned shit. I am proud to declare myself an indecent critic: a critic with a body.

\section{WORKS CITED}

Brody, Howard. Stories of Sickness. New Haven: Yale University Press, 1987.

Butler, Judith. Bodies That Matter. New York: Routledge, 1993.

Bynum, Caroline Walker. Holy Feast and Holy Fast: The Religious Significance of Food to Medieval Women. Berkeley: University of California Press, 1987.

- "Why All the Fuss about the Body? A Medievalist's Perspective." Critical Inquiry 22.1 (1995): 1-33.

Cioran, E.M. Tears and Saints. Trans. Ilinca Zarifopol-Johnston. Chicago: University of Chicago Press, 1995.

Culley, Margo. American Women's Autobiography: Fea(s)ts of Memory. Madison: University of Wisconsin Press, 1992.

de Man, Paul. "Autobiography as De-Facement," MLN 94, 1979, 91930.

Didion, Joan. "Why I Write." In Depth. Ed. Karl Claus et al. Orlando, Florida: Harcourt Brace Jovanovich, 1993.

Douglas, Mary. Purity and Danger. 1966. New York: Routledge, 1991. Forster, E.M. Howards End. London: Edward Arnold, 1910. 
Foss, Laurence and Rothenberg, Kenneth. The Second Medical Revolution: From Biomedicine to Infomedicine. London: New Science Library, 1987.

Foucault, Michel. "What is an Author?" Language, Counter-Memory, Practice. Ed. Donald F. Bouchard. Ithaca: Cornell University Press, 1977.

Gilman, Sander L. Disease and Representation: Images of Illness from Madness to AIDS. Ithaca: Cornell University Press, 1988.

Grosz, Elizabeth. Volatile Bodies: Toward a Corporeal Feminism. Bloomington: Indiana University Press, 1994.

Kimball, Spencer W. “The Angels May Quote from It.” The New Era. October 1975.

Kristeva, Julia. Powers of Horror. Trans. Leon S. Roudiez. New York: Columbia University Press, 1982.

Lejeune, Philippe. On Autobiography. Trans. Katherine Leary. Minneapolis: University of Minnesota Press, 1989.

Miller, Nancy. Subject to Change: Reading Feminist Writing. New York: Columbia University Press, 1988.

Rugg, Linda. "Teaching Confessions to Saints: A Non-LDS Professor and her LDS Students." Sunstone 18.3 (1995): 13-17.

Sontag, Susan. Illness as Metaphor. 1977. New York: Anchor Books, 1990.

Tompkins, Jane. "Me and My Shadow." New Literary History 19.1 (1987): 169-178.

White, E.B. Essays of E.B. White. 1977. New York: HarperPerennial, 1992. 